\title{
The Bacteria contamination of red local meat and white imported meat in Samaraa and
} Al-Dour districts

Afrah M. Mohamed

Maysaloon W. Ibraheem

Nuha H. Sadiq

Department of Animal Production, Agriculture College, Tikrit University Tikrit, Iraq

Corresponding author:

narcissusflower@hotmail.com - maysaloon@tu.edu.iq - nuhaalbassam@yahoo.com

$00964772851671 \quad 009647707599653 \quad 009647705140588$

\begin{abstract}
This work conducted to detect the presence of some types of microbial contaminants in local red meat (beef and sheep) and imported white meat found in local markets in Samaraa and Al-Dour district. Were two hundred samples were collected randomly from samara and Al-Dour within Salah Al Din province the samples were planted on different planting medias to show the presence of bacterial contaminants likely to be found in the studied meat samples, The results showed the highest contamination of beef meat with staphylococcus aureus 12.07\%, staphylococcus epidermidis 3.45\%, E-Coli 10.43\%, Salmonella $8.62 \%$ and Bacillus $1.72 \%$. For sheep meat the highest contamination with staphylococcus was $6.90 \%$, E-Coli $6.90 \%$, and Salmonella $3.45 \%$ while did not appear any contamination in staphylococcus epidermidis and Bacillus in sheep meat. In poultry imported meat, staphylococcus aureus conducted high percentage of pollution in three types of imprted meat :American 6.90\%, Turkish (Goza) $6.90 \%$ and Turkish(Asma Uglo)5.17\% while Brazilian chicken conduct lowest percentage of pollution was1.72\%. About E-Coli the percentage were high in the four type of white imported meat. Salmonella did not showed any percentage of pollution in three types of white imported meat except the American type (drum stick) was3.45\%. Also about Bacillus did not showed any percentage of pollution in three types of white imported meat except the American type (drum stick) was $3.45 \%$.
\end{abstract}

Key words :( meat contamination, red meat, white meat, staphylococcus aureus , Salmonella, staphylococcus epidermidis )

\section{Introduction}

Meat is a perishable substance because of the biochemical reactions caused by enzymes during the formation and maturation of the food tissue from the one hand, on the other hand, meat is vulnerable to attacking microorganisms (1989، السلمي واخرون).

That is for this reason, meat industry is important because it play important role in transforming perishable meat into more stable substances, they prevent or delay food corruption at least by using low heat , high temperature , radiation, shortwave and other methods used in food (القيسي واخرون،2004) .

The most important contaminants of meat are salmonella and bacteria staphylococcus aureus that grow on food and produce toxic toxins to public health.

Meat can be a medium to transport pathogenic microorganisms without helping to grow such as tuberculosis and cholera, or to be a center of growth and access to a number of its susceptibility to infections as in salmonella(الشوابكة واخرون،2000).

So the study aimed to:

- To Know the bacteria content of these meat from staphylococcus, E.coli, salmonella and bacillus in imported chicken meats
-Know the bacteria content of these meat from staphylococcus, E.coli, salmonella and bacillus in beef and sheep meat

-Study the replication of these bacteria in two areas in Salah aldin ( Samarra, Al- Dour)

\section{Materials and method}

The study included (200 samples) of local red (beef and sheep meat) from (butchers shop) collected from (Samaraa and Al- dour) in Salah Al Din province. and four types of imported white meat: American(drum stick) Brazilian (Sadia) Turkish(Goza) and Turkish (Asma uglo) collected from the markets in Samara an Al-Dour.

Plant and count the bacteria were according to (مهدي 1987،) method:

1- The samples were subjected to scanning directly into the laboratory and when we can't we put it in the refrigerator to complete work on the second day.

2- The samples were sliced in a grinder machine to obtain a homogeneous sample.

3 -We add $25 \mathrm{~g}$ of meat sample to $225 \mathrm{ml}$ of the physiological salt solution and mixed with the mixer at $2000 \mathrm{r} / \mathrm{min}$ for $3 \mathrm{~min}$. 
4-We took $1 \mathrm{ml}$ of the first dilution and added to the tube containing $9 \mathrm{ml}$ of physiological dilution to obtain the desired dilution.

5-One $\mathrm{ml}$ of the base model was transferred (in a sterile conditions) were applied to the petri dish and the refractory was each diluted.

6-In sterile conditions, added $15-20 \mathrm{ml}$ of medium to each petri dish and mix well with the model by moving the dish forward, back, left and right in a circular way, then wait until the center became hard.

7 -Incubate the dishes upside down in the incubator at $37^{0} \mathrm{C}$ for $24 \mathrm{hrs}$.

8-After the incubation period was completed, the number of constituent units was calculated.

9-Bacterial isolates were identified using biochemical diagnostic tests.

Planting Media : according to (هاشم 2005)

1-Mannitol salt agar:

Used as an electrophysiological medium to isolate staphylococcus bacteria with the present $(\mathrm{NaCl})$ in concentrate $7.5 \%$. Received by (H-media) indian company.

2- Salmonella agar:

Used as an electoral medium to isolate salmonella bacteria received from ( $\mathrm{H}$ - media) Indian company.

\section{Preparation of cultivation:}

1- Mannitol salt agar:

Prepared this medium with a liquefaction of $111 \mathrm{~g}$ in $1 \mathrm{~L}$ of distilled water and heated until boiling to dissolve the mixture and adjust the $\mathrm{pH}$ to 7.4 , after sterilization, refrigerate the medium into45-50 in a water bath and distribute in Petri dishes and leave to be hard.

2- Salmonella agar:

Prepared by dissolve $60 \mathrm{~g}$ of medium in $1 \mathrm{~L}$ of distilled water and protect until boiling with continuous mix, then wait until be cool and put it in a Petri dishes

\section{Results and discussions}

\section{1: Percentage of local beef meat contamination with bacteria in samara district}

The results of this study showed the presence of bacterial contamination in five bacterial strains of beef in samara district, staphylococcus aureus were isolated by $3 \%, 12.07 \%$ and $8.62 \%$ respectively compared with local studies, this results don't agree with (حمزة 2010)found, as the percentage of isolation was $34.4 \%$ in beef meat. While it was higher than what found , it was $5.55 \%$. the contamination of carcasses by staphylococcus aureus, came from either the animal itself or from the hands of the cutters so the intensification of awareness of health and care during the meat trading is important to reduce pollution .

Well for staphylococcus epidermis's we noticed the high percentage was in beef meat $12.07 \%$ this may be due to the length of time the animal is exposed to contaminants due to aging.

As for the $E$-coli , it was isolated in percentage $2 \%$, $10.34 \%$ and $5.17 \%$, respectively compared with the local studies, it was much less than what (الاسود،1987) found it was $80 \%$ in minced beef meat. That is may be due to the low numbers of cattle carcasses.

Also Salmonella Spp. was isolated in 2\% $8.62 \%$ and $5.17 \%$ respectively this difference in percentage may be due to different age of slaughterd animals.

Finally, Bacillaus Spp. was isolated in 1\%, 1.72\% and $0.00 \%$, respectively. It is not agree with (Bergdoll, et al 1990) he found the isolated $22.4 \%$ the source of meat contamination in bacillaus spp either from the contents of the intestine or the surrounding environment (Oauttara et al , 2002).

Table 1. Percentage of local beef meat contamination with bacteria in samara district (\%)

\begin{tabular}{llccccc}
\hline \multirow{2}{*}{ Local } & Samples & \multicolumn{2}{c}{ Mannital salt agar } & \multicolumn{2}{c}{ Salmonella shigella agar } \\
\cline { 3 - 7 } & & $\begin{array}{c}\text { staph. } \\
\text { Aureus }\end{array}$ & $\begin{array}{c}\text { Staph. } \\
\text { epidermidis }\end{array}$ & E.coli. & $\begin{array}{c}\text { salmonella } \\
\text { Spp. }\end{array}$ & \multicolumn{2}{c}{$\begin{array}{c}\text { Bacillaus } \\
\text { Spp. }\end{array}$} \\
\hline Sammaraa & Calf meat 3 months age & 3 & 1 & 2 & 2 & 1 \\
\hline Sammaraa & Calf meat 1 year age & 12.07 & 3.45 & 10.34 & 8.62 & 1.72 \\
\hline Sammaraa & Minced calf meat & 8.62 & 1.72 & 5.17 & 5.17 & 0.00 \\
\hline
\end{tabular}

\section{2: Percentage of local sheep meat contamination with bacteria in \\ Al-Dour district.}

The results of this study showed the presence of bacterial contamination in five bacterial strains of sheep in Al-Dour district, the isolate of staphylococcus aureus showed $6.90 \%, 6.90 \%$ and $3.45 \%$ in sheep meat (10months) , (12months) and ( minced meat), respectively. The minced meat was conducted the low percentage and it was low than $(12,13)$ found $23 \%$ in sheep meat inspite of the low percentage but always prefer to intensify awareness of health among employees and care and hygiene during meat trading to reduce pollution. As for staphylococcus epidermis's isolate did not show a percentage of it in three types of meat .

E-coli isolate was $0.00 \%, 6.90 \%$ and $3.45 \%$ respectively, this percentage was much low than (Chang et al , 2007) found it was $29.2 \%$. It is may be because 
the carcasses wash after the removal of bowels (Alfrod et al , 1971).

Salmonella isolate was $0.00 \%, 3.45 \%, 0.00 \%$ respectively the contamination appeared just in sheep meat (12 months) it was high than the percentage isolate (Fox et al , 1987) found it $2 \%$ in Baghdad, and low than (Acottand et all, 1975) found in Mousl it was 7\%, this difference may be due to the applicability of the applicable health conditions. Finally didn't appear isolated percentage in Bacillus in three types of meat, that is may be because of the removal of the contents of the intestines from the carcass as an important source of bacillus infection.

Table 2. Percentage of local sheep meat contamination with bacteria in Al-Dour district (\%)

\begin{tabular}{llccccc}
\hline Local & \multirow{2}{*}{ Samples } & \multicolumn{2}{c}{ Mannital salt agar } & \multicolumn{3}{c}{ Salmonella shigella agar } \\
\cline { 3 - 7 } & & $\begin{array}{c}\text { staph. } \\
\text { Aureus }\end{array}$ & $\begin{array}{c}\text { Staph. } \\
\text { epidermidis }\end{array}$ & E.coli. & $\begin{array}{c}\text { salmonella } \\
\text { Spp. }\end{array}$ & Bacillaus Spp. \\
\hline Door & Sheep meat 10 months age & 6.90 & 0 & 0.00 & 0.00 & 0.00 \\
\hline Door & Sheep meat 1 year age & 6.90 & 0 & 6.90 & 3.45 & 0.00 \\
\hline Door & Minced meat 3 years age & 3.45 & 0 & 3.45 & 0.00 & 0.00 \\
\hline
\end{tabular}

3: Percentage of imported chicken meats contamination with bacteria in Samaraa and AlDour districts.

The results of this study showed the presence of bacterial contamination in five bacterial strains in four types of imported chicken meats, so the isolate of staphylococcus aureus showed a percentage $6.90 \%$, $1.72 \%$ and $6.90 \%, 5.17 \%$ to the four types of imported chickens meats, the lower percentage was in (Sadia) chickens . These percentages were agree with the results of (Desrosier et all, 1975) he note the fluctuation in the numbers of staphylococcus aureus in frozen chicken meat in the market. This is due to the pollution that may occur as a result of the process of packaging or trading as well as the process of transport and the time spent and temperatures used during storage in the local markets. As well as the value of the PH may be the cause of the growth of these bacteria because they cannot live in conditions with the $\mathrm{pH}$ close to the neutral (Ranjan, 2007).

As for staphylococcus epidermidis the isolate show low percentage it was $1.72 \%$ to the three types of imported chicken meats while the percentage in American chicken was $0.00 \%$. despite the little percentage of these bacteria, but their presence in the samples under study in our climatic and environmental conditions of the hot atmosphere and power outages lead to the development of these bacteria quickly compared to environment of the importing countries.

For E-Coli bacteria the isolate show high percentage in Turkish chickens $6.90 \%$ while the low percentage was in Brazilian chickens $3.45 \%$ this may be due to not exposure to suitable environment stress, making them vulnerable to low temperature resistance (Noyes, 1969) which lead to a decrease in the number of bacteria in frozen storage, it means the freezing was not correct because of the power outages.

The results of Table (3) free of salmonella except the American imported chicken sample it was $3.45 \%$, were found to be in violation of the Iraqi standards (Central Organization for Standardization and Quality Control,2006) the frozen chicken should be completely free from salmonella .

Also Table (3) showed the samples free from bacillaus except the American imported chickens showed $3.45 \%$, the reason may be due to the lack of safety of the equipment and not follow the health conditions properly, as well as pollution during transportation in the hot weather conditions and long exhaustion that takes in the transport vehicles until the arrival to the consumer because of the current conditions of the country.

Table 3. Percentage of imported chicken meats contamination with bacteria in Samaraa and Al-Dour districts (\%)

\begin{tabular}{|c|c|c|c|c|c|c|}
\hline \multirow[t]{2}{*}{ Local } & \multirow[t]{2}{*}{ Samples } & \multicolumn{2}{|c|}{ Mannital salt agar } & \multicolumn{3}{|c|}{ Salmonella shigella agar } \\
\hline & & $\begin{array}{l}\text { Staph } \\
\text { Aureus }\end{array}$ & $\begin{array}{l}\text { Staph. } \\
\text { epidermidis }\end{array}$ & E.coli. & $\begin{array}{l}\text { salmonella } \\
\text { Spp. }\end{array}$ & $\begin{array}{l}\text { Bacillus } \\
\text { Spp. }\end{array}$ \\
\hline Samaraa/AL-Dour & $\begin{array}{l}\text { drum sticks } \\
\text { American }\end{array}$ & 6.90 & 0.00 & 5.17 & 3.45 & 3.45 \\
\hline Samaraa/Al-Dour & Sadia Brazilian & 1.72 & 1.72 & 3.45 & 0.00 & 0.00 \\
\hline Samaraa/AL-Dour & Goza Turkish & 6.90 & 1.72 & 5.17 & 0.00 & 0.00 \\
\hline Samaraa/AL-Dour & Asma Oglo Turkish & 5.17 & 1.72 & 6.90 & 0.00 & 0.00 \\
\hline
\end{tabular}




\section{References}

Acottand K.M., Labuza,T.B.,(1975). Inhibition of Asperrgillus niger in an intermediate moisture food system, J. Food sci. ,40: $137-139$.

Alfrod,J.A., Smith J.L. and Lilly,H.D. (1975). Relationship of microbial activity to changes in lipid of foods, J. Appl. Bact. ,1971, 34:133. 11) H.C. Chang \& Branen, Antimicrobial effect of butylated hydroxy كاظم 2007).

Bergdoll,M.A.(1990). Staphylococcus food poisoning, in cliver, D.O.,food borne disease. Academic Press,Inc (cited by كاظ2007).

Chang H.C., and Branen. (1975). Antimicrobial effect of butylated hydroxy anisole (BHA), J. Food Sci., 40: 349- 351. 12) V. Bulletin V3, o, o, Release Codidate 4, Jel Soft Enter prises Ltd., 2005. (cited by كاظم 2007).

Debeaufort, F., Quezada - Gallo, J.A. and Voilley, A., (1998). Edible Films \& coating, tomorrow's packaging, a review. Crit. Rev. Food Sci., 38: 299 313.
Desrosier,N.W., (1970). the Technology of Food Preservation, 3rd edition, Avi Publishing Co. Westport Conn. (Cited by 2007 ).

Fox,J.B.,)1987). The pigment of meat, The science of meat \& meat products, Eds. Price, J.F. \& B.S. Schweigerm, Food \& Nutrition Press, Westport. CT.

Gyles,C.L., Rescott,J.F., Songer,J.G. and Thoen,C.O. (2004). Pathogenesis of bacterial infection in animals, third edition, balck well puplishing.

Noyes,R. (1969). Protein food supplementation, Noyes Data Corporation, New Jersey, U.S.A. (Cited by 2007 كاظم).

Oauttara,B., Sabato S.F. and Lacroix,M.(2002). Use of gamma - irradiation technology in combination with edible coating to produce shelf - stable foods, Radiat. Phys. Chem.,63 :305 - 310.

Ranjan, K.D.,(2007).0TTextbook0T of Diagnostic microbiology.medical college and hospital ,medical publishers (p) Ltd Newdelhi .PP: 124. 


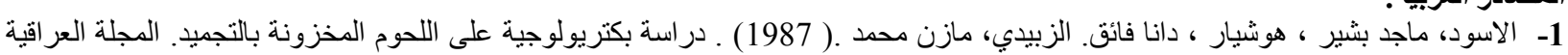

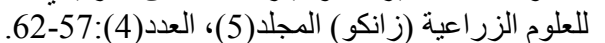

$$
\begin{aligned}
& \text { 2- الجهاز المركزي للتقييس و السيطرة النوعية (2006). الحدود المايكروبية للحوم ومنتجاته. المو اصفة القياسية العر اقية رقم ( 4/2270)ج. } \\
& \text { 3- السلمي أ.ع و علي ز.م. (1989). تجارب مختارة في الاحياء المجرية ، وزارة التعليم العالي والبحث العلمي ، جامعة البصرة. } \\
& \text { 4- الثوابكة ، محمد و.خ (2000). اهم امر اض الدو اجن المعدية في الاردن ، الطبعة الاولى ، مطبعة السنابل،الاردن ص24-49. } \\
& \text { 5- القيسي م.ض. ،السامر ائي س.ع.أ و صبري ع.ب (2004). مجلة العلوم المستنصرية } 2004 \text { ، المجلد (15)، العدد(3)، ص(37). } \\
& \text { 6- حزة،اسيل محمد ، عباس،ميسون صباح ، احمد ، وفاء عبد الاله ،(2010 ). عزل وتثخيص اهم البكتريا المرضية من اللحوم الحمر اء الطازجة . }
\end{aligned}
$$

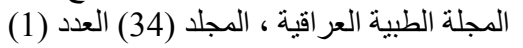

$$
\begin{aligned}
& \text { 7- كاظم، زينة محمد. (2007) . دراسة تلوث بعض انواع اللحوم المحلية والمستوردة. مجلة جامعة كربلاء، المجلد(5) ، الاصدار(4)، الصفحات:5-5 } \\
& \text { 8- مهذي ع.ع (1987) الكيمياء الفيزيائية لمنتجات الاغذية، وزارة التعليم العالي و البحث العلمي، جامعة بغداد،1987. } \\
& \text { 9- هاثم، عالية زيارة (2005) ـ دراسة مقارنة في الصفات النو عية بين الدجاج المجمد المعروض في اسواق مدينة البصرة و الدجاج الدجد مختبريا . } \\
& \text { رسالة ماجستير ، كلية الزراعة_جامعة البصرة }
\end{aligned}
$$




\section{التلوث البكتيرى فى اللحوم الحمراء والبيضاء المحلية والمستوردة فى قضاء سامراء والدور \\ أفراح مصطفى محمد - ميسلون وائل إبراهيم - نهى صادق حميد \\ قسم الانتاج الحيوانى - كلية الزراعة جامعة تكريت - العراق مئق}

اجريت هذه الدراسة لغرض الكثف عن وجود بعض أنواع الملوثات الجرثومية في اللحوم الحمراء المحلية في العراق (لحوم ابقار وأغنام) والبيضاء المستوردة الموجودة في الاسواق المحلية في قضائي سامراء والدور ، حيث نم جمع 200 عينة وبصورة عشوائية من قضائي سامراء والدور ضمن محافظة

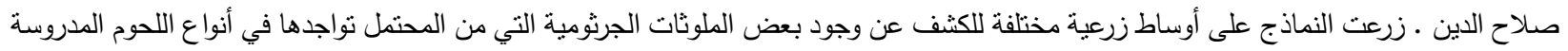
وأظهرت النتائج أعلى نلوث للحوم العجول بالمكورات العنقودية 12.07 \%والمكورات العنقودية البشروية 3.45 \% والأيشريشيا القولونية 10.34 \%والسالمونيلا 8.62 \% والباسلس 1.72\%. أما بالنسبة للحوم الأغنام فان أعلى تلوث لها بالمكورات العنقودية الذهبية 6.90 \%والاشريشيا القولونية 6.90 \% 60

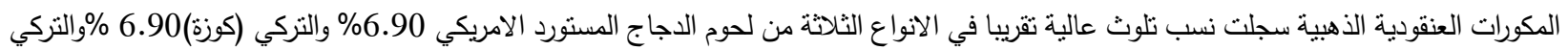
(اسما اوغلو) 5.17 \%بينما سجل الدجاج البرازيلي اقل نسبة تلوث بلغت 1.72 \%، أما بالنسبة لبكتبريا الأيشيريشيا القولونية فقد كانت مرتفعة في الانواع

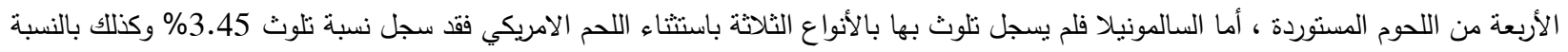

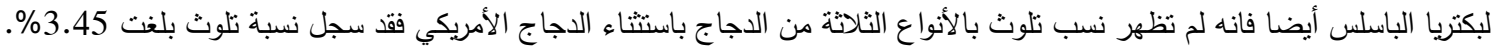
الكلمات المفتاحية: ( تلوث اللحوم، اللحوم الحمراء،اللحوم البيضاء، بكتريا القولون، الدكورات العنقودية الذهبية، السالمونيلا) 